\title{
FOUNDATION FOR A NATIONAL POLICY ON LOCAL GROWTH AND LOCATION OF FEDERAL EXPENDITURES
}

\author{
Robert W. Raynsford, Jr. and Curtis C. Harris, Jr. *
}

U.S. Office of Management and Budget and University of Maryland

\section{Introduction}

The interest in formulating a national policy on regional growth has been increasing over the past several years. This interest has been expressed both in terms of seeking a national policy on population distribution and national policy on the location of economic activity. Both are essentially formulations of the same problem since in a long-run equilibrium situation, which must be the objective of policy, the location of economic activity and if the population are the same. There are, however, three separable types of concern about the current and projected future distributions of population and economic activity. The first concern is with the type of a rea in which a person lives and works. Is it a large, medium-sized, or small metropolitan area? Is it a small town or rural area? The second concern is whether all regions, States and larger sections of the country share in more or less equal measure in the national economic growth. The third concern is whether in the absence of a national policy individual agencies may be working at cross purposes.

These three concerns do not exhaust the possibilitis of what could motivate a national policy on population distribution or the location of economic activity. Within metropolitan areas, for example, one may be concerned with the distributions of population and jobs between suburban and central city portions of the entire metropolitan area. Within this context, of course, differences between the location of population and of jobs are possible and highly relevant to all as pects of local government operations. The fact that the re are significant differences between the locations of residence and work within large metropolitan areas and that the locational differences mean crossing jurisdictional boundaries have contributed to many of the conditions (such as traffic congestion, air pollution, poor performance in schoolintegration, and problems of local finance) which have greatly increasedpressure to formulate a national policy on local growth. The following discussion focuses both on questions relating to the overall size of metropolitan areas and others relating to locational patterns with metropolitan areas.

In the formulation of a national policy on the location of persons and jobs several sequential problems must be solved. The first is the formulation of a consistent set of perferences for the location of activity among types of area and regions of the country. The second is an analysis of whether forces at work in the economy without any changes in Government policy have brought or may be expected to bring actual location in line with locational

* The research upon which this paper is based was supported by a research grant from the Economic Development Administration, U.S. Department of Commerce. The interest of Jack W. Carlson and William A. Niskanen, Office of Management and Budget (OMB) and contributed to completion of this paper. In addition, the authors would like to acknowledge helpful review and critique by the members of the Program Evaluation Division of OBM and by Martin C. McGuire and Mancur Olson of the University of Maryland. 
preference. Only after completion of these first two steps can one conclude that adoption of some new policy might be warranted. The third step comprises calculations of the benefits which might be derived from some (still unspecified) policy which would be capable of changing the location of economic activity in desired directions. Only as a fourth step can examination of possible policies be undertaken. If estimates can be made of their costs and impacts, then comparision may be made with benefits attributable to given impacts, and finally some rational decision can be made concerning which policies are worthwhile to adopt.

A logical set of preferences for location of activity and growth may be based on identification of those areas where the benefits of activity or growth most exceed the associated costs. In a world in which all costs and benefits were received directly by those who choose to locate someplace, $\underline{A}$, rather than another place, $\underline{B}$, no discussion should ever arise concerning the need for national policy on local growth. There are several reasons, if fact, why the full costs of locational decisions are not borne by those who decide to move or to expand operations without moving. The first of these is that there is a distinct set of social costs which are borne by the community as a whole. Some of these show up as Government expenditures, especially those of local government, such as police and fire protections, education and highway construction. Others show up as socioenvironmental indicators, such as air pollution, traffic congestion, and crime rates. Presumably there is a relationship between expenditures of local government and socio-enviromental indicators. Nevertheless all measures should be used simultaneously in measuring social costs.

As a member of the community the immigrant will feel at least some of the impact of the se social costs and to this extent his choice will be influenced by them. There is, however, no guarantee that he will bear the full social cost associated with his locational decisions. If the social costs of further growth for some community are rising, even payment of average cost per person attributable to each type of social cost will insure payment less than the marginal contribution to social cost. The difference between marginal and average costwill be borne by other members of the community, and average costs will, of course, rise. There is, furthermore, no guarantee that the agent of further growth will pay even average social cost associated with the new level of economic activity. The marginal locator may be better protected than the average member of the community from feeling the impact either financial or physical of the social costs prevailing in any community. Some of this effect may be attributed to jurisdictional boundaries between place of residence and place of work and their effects on tax liability and level of local government services. Additionally, it may be that place of location within the community provides a degree of insulation from the prevailing average levels of social cost regardless of protection which may be afforded by jurisdictional boundaries.

Policies themselves may be divided into four general categories. One type attempts to reduce private costs by acting directly to reduce social costs where they are highest. Another type of policy attempts to induce additional growth by providing subsidies to the private sector for locating in areas with high private costs. The result of both of these first two types of policy, if successful, is usually to induce more growth in areas characterized by both high social and private costs. The third and fourth types of policy seek to induce more growth in areas of low social cost either by providing additional incentives to private industry or by increasing the extent to which all relevant costs enter into private locational decisions. This last type of pol- 
icy attempts to reduce social costs as a fraction of total costs.

Apart from the problem of a local depressed economy, which can include the central city of a metropolitan area as well an isolated rural community, no one could seriously argue for measures to induce location in high-cost areas. These are, however, exactly the cases which have received the most attention in terms of economic development policy and virtually the only ones whose development has been the objective of Federal programs. Insofar as they are high cost areas, Federal programs for their development are in fact making use of the first two types of policy but not of the third or fourth. There is one exception to this generalization - the growth center program for the development of isolated rural areas. This program operates, or seeks to operate, on the location of persons rather than growth by helping to bring persons from areas where the costs of growth are high to the growth centers, where the costs are imputed to be lower.

The focus of this paper, however, is broader than the problems of depressed economies although social cost data a re analyzed for country groupings - the central city and rural counties - which are likely to be characterized by particularly severe economic problems. By broadening to include metropolitan and urban areas of all sizes, this study attempts to marshal evidence for a general preference in the location of economic growth. It deals with groupings most of which are not considered economic problem areas. In the more general setting it is difficult to conceive of any set of circumstances which could lend support to a policy of inducing additional growth in the higher cost areas (policy types one and two). If a general policy is advisable the choice will be between the third and fourth types of policy. The fourth type - increas ing the extent to which social costs aretransformed into private costs - is most powerful in reducing the total costs of economic growth and for this reason should generally be favored, unless institutional or administrative difficulties make its adoption infeasible.

\section{Evidence on Variation in Social Costs by Type Area}

The above presents only a skeletal outline of conceptual factors relating to national policy on local growth. Without tying these considerations to the available relevant data, however, one is really no nearer to formulation of a set of preferences for the location of economic activity and growth. In economics theory can quickly outrun the availabilty of data, and it is worthwhile to learn rather early in the discussion the most that can be gleaned from the data at hand. Fortunately it has been possible to study variation in social costs which may be revealed by selected expenditures of Federal and local government as well as socio-environmental indicators. The basic unit of observation has been the county. Counties have been grouped into Standard Metropolitan Statistical Areas (SMSA's) of four different sizes, into nonSMSA urban areas and into rural areas. Additional groupings include all central city counties within SMSA's and for a sample of SMSA's suburban and central city counties. The special sample selects only those SMSA's in which at least 75 percent of the population of the central city county lives within the central city, in other words those SMSA's for which county data may really be used to discriminate between central city and suburban areas. The fact that the total population of SMSA's within the sample was less than one-third of the population of all SMSA's is an indication of the limitations of even county data in discriminating among types of area.

For these groups, variation in the expenditures for general local government, education, welfare, police protection, and local transportation and variation in health and crime indicators have been examined. The results 
are presented in Tables I-VI. The tabulations do not purport to represent a rigorous explanation of the variation in social costs. Expenditures do not correspond to any pure concept of social cost since variation both in local government efficiency and quality of government services are ignored. Also factors such as the economic and demographic characteristics of the local population may influence both public expenditures and socio-environmental indicators. More formal analysis would have to test the significance of all these omitted variables as well as give more rigorous definition to urban size and density groupings. The remainder of this section should be viewed as a preliminary form of analysis, or perhaps, as the starting point for a more formal analysis. Nevertheless it is thought worthwhile to report such preliminary analysis because of a probability that more formal analysis would not eliminate size of metropolitan area as a highly significant factor in explaining variation in social costs and that the conclusions which are suggested by the preliminary analysis would be sustained by subsequent study.

In the General Local Government table the expenditures for fire protection per capita decline with the size of SMSA but then rise again for the non-SMSA urban counties. This pattern, which was frequently identified in the course of the analysis suggests real economies of scale moving from non-SMSA urban areas to SMSA's of less than 250,000 persons. It also suggests diseconomies of scale which begin to become apparent for all SMSA's over 250,000 persons and which are evenstronger than the economics of scale for SMSA's of over one million persons. Expenditures for sanitation per capita demonstrate another frequently encountered pattern in which diseconomies of scale appear to dominate all urban size classes. The rise in expenditures per capita moving from smaller to larger urban areas, however, has a rather mild gradient through SMSA's of up to 500,000 and then a much steeper one. In the aggregate, expenditures of general local government per capita assume the shape of an average cost curve with a minimum for SMSA's under $250,000.2$ Using the groupings of SMSA counties into central city and suburban, one finds that without exception expenditures for local government per capita are higher for central cities. The spread between expenditures for all central city counties and for the special sample suggests the importance of careful selection of county data to represent central cities. Local government outlays for fire protection and sanitation, as well as total local government expenditures, are considerably higher for central cities in SMSA's of all sizes than for SMSA's of over one million, which represents the size class for which these expenditures are highest.

Local transportation is represented by two types of expenditure, Federal Government outlays for urban mass transit and local highway expenditures. These latter assume the shape of an average cost curve with minimum for SMSA's of less than 250,000 . The steeper rise, however, in contrast to the curves discussed under General Local Government is for the smallest size urban areas. This result could undoubtedly be related to lower population densities of the smallest urban areas and suggests the significance of this factor in determining local transportation outlays per capita. The difference between expenditures per capita incentralcities and in suburbs is very small and suggests that the opposite effects of higher cost per mile of construction in central cities and the greater number of miles per capita constructed in the suburbs may largely cancel one another. Concentrated in the central cities and the largest SMSA's, Federal outlays for urban mass transit should act as a damper on local highway expenditures in these areas. Adding the two series to obtain a more complete picture of localtransportation outlays, one sees progressively larger increases in expenditures for the larger size classes and the clear emergence of higher outlays for central city rather than suburban areas. 
Local expenditure per personunder fifteen ${ }^{3}$ for elementary and secondary education reveals another pattern of outlays in the shape of an average cost curve with minimum for SMSA's under 250,000. The pattern for Federal outlays is almost exactly the converse with a maximum for SMSA's between 250 and 500 thousand. Since local expenditures include those financed with Federal and state revenues i.e., grants in aid, the distribution of local expenditures is largely the sum of Federal, state and local efforts. Local expenditures from state and local revenues only, therefore, would show an even more emphatically defined minimum for SMSA's under 250, 000 then local expenditures as shown in Table III. Furthermore, social costs may be associated with the degree of school integration. Indices of school intergration, which take account of the racial composition of each county, indicate highest degree of integration for the smallest SMSA's and non-SMSA urban areas. In comparisons among SMSA's of different size classes even though no monetary values are attached to the social costs of segregation, the integration indicators imply that average social costs in education are even lower for the smallest SMSA's relative to those for the largest SMSA's than could be concluded from examination of public expenditure data alone.

Examination of educationaloutlays for central cities and suburbs with in SMSA's reveals considerably higher local expenditures per person under 15 for the suburban areas which are only partially compensated by Federal expenditures within the central cities. If the quality of education both within the central cities and suburbs is roughly comparable, then these figures may really represent economies of scale in the central cities. On the other hand, they may represent a willingness on the part of suburbancounties to pay for more quality in primary and secondary education. Furthermore, social costs associated with school segregation would appear to be much higher for the central cities. On balance it may be that costs for education of some given quality are relatively higher in central cities.

The social costs of crime rise with size of urban area, and the rise accelerates rapidly moving from SMSA's under one million to those over one million. In addition, the cost of crime in the centralcities is far higher than that in the suburbs. The differences are visible both in the local expenditures per capita for police protection and in data on crimes per thousand population. Table IV displays data on robberies, whose reporting is relatively accurate and consistent among different areas. 4 The rather steep rise in expenditures per capita moving into the largest size class does not prevent an even greater acceleration in the rise in robberies. The socialcost of crime in the centralcities within SMSA's of all size classes, moreover, is considerably higher than that of the largest SMSA's taken as a whole. Federal law enforcement assistance in 1969 concentrated on central city rather than suburban a reas but gave least support on a per capita bas is to the largest SMSA's. 5

In using health indicators to study variation in the social costs of economic growth for different types of a rea, one must present evidence that certain types of area provide basically a less healthy environment than others. Using variation in health services and care or hospital construction expenditures, however, may not provide appropriate indications for several reasons. In addition to the need for health services and care other factors, such as variation in income distribution and economies of scale, may both be at work skew the distributions toward the largest metropolitan areas and within them toward the central cities. Furthermore, there is remarkably little variation by size of metropolitan area in general health indicators, such as infant mortality and age-adjusted death rates. Deaths from respiratory ailments, which may be related partially to local air quality, appear to be some- 
what more concentrated in the largest metropolitan areas than in smaller ones and within SMSA's these deaths are clearly more concentrated in central cities. Overall the evidence presented in Tables V and V (a) may indicate some health-related social costs of growth in the largest metropolitan areas even if one discounts the indicator value of health outlays entirely. If Federal and local expenditures for health services were considered to be valid health indicators, the conclusion woul clearly be reinforced.

There is a large variation in local expenditures per capita for welfare both by size of urban area and between central cities and suburbs. Outlays are at a minimum for SMSA's of less than 250,000 and expenditures of central cities are much higher than for suburbs and higher than for SMSA's of any size class. This is a familiar pattern, but its interpretation is quite different than that offered for any of the preceding indicators. The factors which determine local welfare expenditures per capita are the local laws concerning determination of eligibility and levels of support and secondarily concentrations of eligibles, for example, within central cities. These factors are not inherent in the type of area. Economic growth in the areas of highest per capita welfare outlays may, if fact, act to mitigate the burden of welfare expenditures both by providing additional employment and by spreading the burden over a larger tax base. High welfare expenditures per capita may provide an indicator of relatively lower rather than higher social costs of economic growth. This conclusion is consistent, of course, with the realization that the re may be high social costs both of econcentrations of poor persons and of wide variation in welfare burden.

The distribution of Federal income security expenditures, whichexclude all retirement programs but include both unemployment insurance payments and the food distribution programs, is similar to that for local welfare. Variation in local levels of support and in eligibility requirements established at the local level can influence the distribution of Federal expenditures through the mechanism of matching requirements attached to the Federal programs. There is, however, a significant difference warranted in the interpretation of the distribution of the Federal outlays. The tax burden cannot be alleviated by encouraging growth where welfare costs are high unless the argument can be made that such a strategy would reduce the overall burden by reducing the number of eligibles more effectively than another pattern of growth. In any case the evidence which is being weighed in this paper could not support such an a rgument.

The tabulations of social indicators by type of a rea in Tables I-VI include a rural area as well as the various urban areas. The social costs associated with the rural area, however, have not entered into the discussion of alternative locations of economic activity and growth for the reason that preference for this type of area would transform it into one or more of the types of urban area. Nevertheless the values which the social indicators assume in the rural a rea a re of use in providing a check on the manner in which they have been interpreted. The low expenditures per capita for fire protection and sanitation in rural areas and the especially high outlays in the se categories for central cities appear to reflect the influence of population density on these expenditures. Local highway expenditures per capita on the other hand show a rise for the rural areas which may reflect a diseconomy associated with low population density. Local rural expenditures on primary and secondary education are somewhat higher per person under 15 than the minimum but not as much as one would expect given a strong presumption of diseconomies associated with low population density for this category. One suspects as in the case of the difference in expenditures levels between centralcity and suburban areas that significant quality differences are present. Insofar as this is true, the indicator value of the statistic is commensurately weak. 
ened. The higher infant mortality rate in rural areas probably does not indicate that they are less healthy places to live but rather that they are not adequately reached by medical services. This possibility serves to emphasize the importance of using health expenditure and indicator data jointly in drawing any conclusions concerning preference for the location of growth. The higher level of deaths from respiratory ailments in rural areas cannot be taken as a general environmental indicator. It probably reflects continued presence of one of the occupational hazards of mining, which is located primarily in rural areas. Finally the expenditures per capita on welfare represent the low end of the scale in terms of local levels of support for poor persons.

If the tax burdens of local welfare within largest SMSA's and central cities and the lower levels of supportfor the rural poor could be removed through introduction of a truly national welfare system, welfare indicators by type of a rea could be effectively removed from discussion of national policy on local growth. The remaining evidence, even though some of it is quite weak and some must be rejected entirely, does seem to indicate that social costs associated with economic growth are at their lowest point for SMSA's under 250, 000 and lower for suburban rather than central city growth.

\section{Variation in Actual Growth Compared with Variation in Social Costs}

There may be some reason to consider a national policy on local growth in the sense of a policy to influence the location of most rapid growth when difference between the areas of lowest social cost and the area of actual most rapid growth are established. During the most recent decade Table VII shows average annual rates of growth in population to have been highest for SMSA's between 500 thousand and one million. This group, moreover, appears to have increased its lead over other metropolitan areas and the nation as a whole during the later part of the decade. While the areas of highest growth are not those identified tentatively as the areas of the highest social costs of growth neither are they the areas of lowest social costs of growth. Under these conditions the possibility doesexist.that some national policy to influence the location of growth may be warranted. Within SMSA's however, the suburban areas grew much more rapidly then the central cities and increased their lead in average annual rates of population growth during the latter part of the decade. Since these may be areas where the social costs of growth are low, this pattern would be consistent with locational preference. In addition, the discrepancies between social costs of growth in the central cities and suburbs may help to explain the observed differences in social costs among SMSA's of different size classes. If the ratio of central city to suburban population is invariant to city size, lower suburban costs would affect overall SMSA costs about equally for metropolitan area of all sizes. If, however, suburban areas form a significantly higher proportion of total propulation in the smaller SMSA's, this factor could explain some of the observed variation in social costs by size of SMSA. Specifically degree of suburbanization would be one variable to be tested in a formal analysis of variation in social costs among areas.

\section{The Location of Federal Outlays}

Abondonment of the idea of policy to influence private decisions on the location of economic activity does not imply giving up all concern for the location of Federal outlays. Some major categories of Federal expenditures may be quite significant in determining the location of economic growth throughout the country, 7 and these may be examined with regard to the social 
costs prevailing in these areas in which they are concentrated. It may still be possible and desirable to establish policies to affect the location of Federal outlays. The four categories which have been singled out for especial examination because of their magnitude and probable impact on local area growth are (1) defence payrolls, (2) defense contracts, (3) atomic energy and (4) space research and technology. These outlays have been studies to identify relative concentrations in a reas characterized by especially high or low crime rates, air pollution, water pollution, and automobile density. 8 For these last three indicators data were not available for all counties. Air pollpollution data were available for 326 counties, which together contain 54 percent of the U.S. pollution. Water quality data were available from 511 stations. Unfortunately, however, it was not possible to obtain the same type of water quality data from each of these stations. Two separate measures of water quality were used where available, and Tables VIII-XI make use of county rankings calculated from one of them. ${ }^{9}$ Finally data on automobile density relate only to counties within SMSA's.

Defense payrolls show highest concentrations relative to population in SMSA's under 250,000, and at the same time show a tendency to be located in the groups of counties with less air pollution, less water pollution, and lower auto densities within SMSA's. Defense contracts, on the other hand, show concentration in the largest SMSA's. Nevertheless within the areas for which air pollution data were available there was some tendency for expenditures to be concentrated in areas of less air pollution, and there was no strong tendency for outlays to be concentrated in central city rathe $r$ than suburban areas. Atomic energy outlays are somewhat concentrated in the smaller urbanareas and also in those of leastcrime and less water pollution. Space research and technology is concentrated in the largest SMSA's and especially in the suburban areas. In addition, it is more concentrated in the SMSA counties with highest auto density and in the counties with less air pollution.

The overall conclusions which may be drawn from these locational indicators are that important categories of Federal expenditure whichmay affect the location of economic activity and growth, including defense pay rolls and atomic energy, tend to be concentrated in areas where the social costs of growth appear to be relatively low. Other important expenditure categories, including defense contracts and space research, are more concentrated in the largest SMSA's where the social costs of growth appear to be higher. Nevertheless, any negative locational aspects of space research may be compensated by the tendency to favor suburban rather than centralcity areas. Finally even in the case of defense contracts, further study would be required before any case could be made for establishing a policy to influence the location of activity associated with these contracts. The real economic impact of defense contracts is a function of the location of subcontractors as well as prime contractors, although this study was limited to the latter. Tendency for subcontractors to locate in smaller SMSA's and in suburban areas could modify the pattern which is presented by location of prime contractors. Many complete analysis of the locational patterns of defense contractors may be warranted. Without more evidence than this study has been able to present, however, it will not be possible to make a case for establishing a policy on the location of Federal outlays to affect the location of economic growth.

Independent of their role in affecting the location of economic growth, Federal expenditures of different types are supposed to be directed toward solving particular problems. Corresponding to many Federal programs a re socio-environmental indicators which may be used to indicate the degree of 
concentration of each of these programs in areas where the problems to which they are addressed are most severe. Comparisons between indicator and program data may lead to program redirection in the interest of improved targeting of effort. Table XII present comparisons for seven significant Federal programs. The education and housing indicators, deriving from the 1960 Census of Population, may be somewhat out of date but all the others are roughly contemporaneous with the Federal expenditure data. Law enforcement assistance in 1969 was quite concentrated in those counties with the highest crime rates, and those with the least crime received little. Expenditures for air pollution control were twice as concentrated in those counties where air pollution is relatively worse. Expenditures for water pollution control, however, appear to be independent of the location of water pollution. Even taking account of the fact that the location of treatment plants and the measurements of the pollution which they are designed to alleviate may not always be in the same county, one would expect some tendency to concentrate in areas of more severe water pollution. Perhaps tracking the expenditure data over several years would reveal the expected expenditure pattern. Nevertheless the evidence remains still positive that expenditures for water pollution control in 1969 were not being strongly directed to areas of the country with the highest levels of water pollution.

Expenditures for urban mass transit display the expected pattern of being highly concentrated in those SMSA counties of lowest auto density, which are in face the central city counties of the largest SMSA's. Displaying these expenditures in relation to automobile densities tends to emphasize their role as an automobile substitute, which is most needed in the urban setting where there are fewest automobiles per capita.

None of the remaining Federal programs are strongly directed toward those areas where the needs, as revealed by the indicator data, are greatest. Although Federal grants for elementary and secondary education showed some tendency to be concentrated in the counties with the lowest percentage of population over 25 who had completed high school, the same program was also slightly concentrated in those counties with the highest percentage of high schoolgraduates. Relative to their population, moreover, counties with the lowest percentage of soundhousing units received less than their proportionate share of Federal outlays for housing and community aids. Finally a quite low percent of Federal expenditures for health services and care is located in those counties with the highest infant mortality rates, which are probably the best single indicator of general health level.

Table I. General Local Government

\begin{tabular}{|c|c|c|c|}
\hline & $\begin{array}{c}\begin{array}{c}\text { Fire } \\
\text { protection }\end{array} \\
\$ / \text { pop. }\end{array}$ & $\frac{\text { Sanitation }}{\$ / \text { pop. }}$ & $\frac{\text { Total }}{\$ / \text { pop. }}$ \\
\hline SMSA's 1 million & 10.8 & 17.0 & 414.5 \\
\hline 1 million SMSA 500 thousand & 9.4 & 16.3 & 332.6 \\
\hline 500 thousand SMSA 250 thousand & 7.7 & 12.6 & 314.1 \\
\hline 250 thousand SMSA & 7.4 & 12.4 & 281.7 \\
\hline Non-SMSA urban & 10.2 & 10.0 & 295.0 \\
\hline Non-SMSA rural & 2.6 & 5.7 & 260.0 \\
\hline Central city counties & 10.7 & 16.8 & 385.5 \\
\hline Suburban counties & 6.4 & 12.1 & 322.2 \\
\hline $\begin{array}{l}\text { Central city counties (sample) } \\
\text { Suburban counties (sample) }\end{array}$ & 14.1 & 19.0 & 484.1 \\
\hline Suburban counties (sample) & 7.6 & 13.2 & 346.1 \\
\hline
\end{tabular}

Data source: 1967 Census of Local Government Finances. 
Table II. Local Transportation

\begin{tabular}{|c|c|c|}
\hline & $\begin{array}{l}\text { Federal urban } \\
\text { mass transmit } \\
\$ / \text { pop. }\end{array}$ & $\begin{array}{c}\begin{array}{c}\text { Local } \\
\text { highways }\end{array} \\
\text { \$/pop. }\end{array}$ \\
\hline SMSA's >1 million & 2.1 & 21.3 \\
\hline 1 million $>$ SMSA $>500$ thousand & 1.1 & 21.0 \\
\hline 500 thousand $>$ SMSA $>250$ thousand & 0.3 & 20.7 \\
\hline 250 thousand $>$ SMSA & 0.1 & 20.2 \\
\hline Non-SMSA urban & 0.0 & 26.0 \\
\hline Non-SMSA rural & 0.0 & 27.4 \\
\hline Central city counties & 1.7 & 21.1 \\
\hline Suburban counties & 0.3 & 21.0 \\
\hline Central city counties (sample) & 3.1 & 19.9 \\
\hline Suburban counties (sample) & 0.5 & 21.1 \\
\hline
\end{tabular}

Data source: Federal Outlays, 1969 (compiled by the Office of Economic Opportunity); 1967 Census of Local Government Finances.

Table III. Education

\begin{tabular}{|c|c|c|c|c|c|}
\hline & $\begin{array}{r}\text { Lo } \\
\mathrm{Sch}\end{array}$ & $\begin{array}{l}\text { ocal } \\
\text { hools }\end{array}$ & $\begin{array}{r}\text { Integ } r \\
\text { indi }\end{array}$ & $\begin{array}{l}\text { ation } \\
\text { ices }\end{array}$ & $\begin{array}{c}\text { Federal } \\
\text { Elementary } \\
\text { and } \\
\text { Secondary }\end{array}$ \\
\hline & & \$/pop. & & Vari- & \$/pop. \\
\hline & \$/pop. & 15 & $\underline{\text { Balance }}$ & ance & 15 \\
\hline SMSA's > 1 million & 147.2 & 498.2 & .344 &.$\overline{548}$ & 29.3 \\
\hline 1 million $>$ SMSA> 500 thous and & 137.2 & 433.2 & .328 & .539 & 44.8 \\
\hline 500 thousand $>$ SMSA $>250$ thousan & $\mathrm{d} 138.0$ & 433.3 & .320 & .534 & 52.8 \\
\hline 250 thousand $>$ SMSA & 127.8 & 396.8 & .388 & .627 & 47.7 \\
\hline Non-SMSA urban & 135.6 & 438.6 & .467 & .744 & 37.8 \\
\hline Non-SMSA rural & 132.5 & 422.8 & .427 & .713 & 43.7 \\
\hline Central city counties & 135.7 & 446.5 & .312 & .487 & 42.7 \\
\hline Suburban counties & 165.6 & 515.0 & -- & -- & 22.8 \\
\hline Central city counties (sample) & 123.8 & 435.3 & .291 & .439 & 58.7 \\
\hline Suburban counties (sample) & 176.0 & 549.4 & .441 & .739 & 25.7 \\
\hline $\begin{aligned} \text { Data source: } & 1967 \text { Census of Loc } \\
& \text { ion Index and Balar } \\
& \text { lished data, Office } \\
& \text { piled by the Office }\end{aligned}$ & $\begin{array}{l}\text { al Gove } \\
\text { nce Inde } \\
\text { of Civil }\end{array}$ & $\begin{array}{l}\text { rnment } \\
\text { l for } S \\
\text { Rights }\end{array}$ & $\begin{array}{l}\text { Finances } \\
\text { chool Yea } \\
\text { Federal }\end{array}$ & $\begin{array}{l}\text { s; Stud } \\
\text { r } 1968 \\
\text { Outlay }\end{array}$ & $\begin{array}{l}\text { nt Integ rat- } \\
-69 \text {, unpub- } \\
, 1969 \text { (com- }\end{array}$ \\
\hline
\end{tabular}

Table IV. Justice

\begin{tabular}{|c|c|c|c|}
\hline & $\frac{\text { Protection }}{\$ / \text { pop. }}$ & $\frac{\text { Robberies } /}{1,000 \text { pop. }}$ & $\begin{array}{l}\text { Law } \\
\text { Enforcement } \\
\text { Assistance } \\
\text { \$/pop. }\end{array}$ \\
\hline $\begin{array}{l}\text { SMSA's }>1 \text { million } \\
1 \text { million }>\text { SMSA }>500 \text { thousand }\end{array}$ & $\begin{array}{l}20.83 \\
13.01\end{array}$ & $\begin{array}{l}2.728 \\
1.089\end{array}$ & $\begin{array}{l}.22 \\
.48\end{array}$ \\
\hline $\begin{array}{l}500 \text { thousand }>\text { SMSA }>250 \text { thousand } \\
250 \text { thousand }>\text { SMSA } \\
\text { Non-SMSA urban }\end{array}$ & $\begin{array}{r}10.77 \\
9.81 \\
8.60\end{array}$ & $\begin{array}{l}0.851 \\
0.594 \\
0.255\end{array}$ & $\begin{array}{l}.71 \\
.61 \\
.27\end{array}$ \\
\hline
\end{tabular}


Non-SMSA rural

Central city counties

Suburban counties

Central city counties (sample)

Suburban counties (sample)

\begin{tabular}{c}
$\begin{array}{c}\text { Police } \\
\text { Protection }\end{array}$ \\
\hline$\$ /$ pop. \\
5.55 \\
18.12 \\
11.63 \\
26.02 \\
13.65
\end{tabular}

Data sources: 1967 Census of Local Government Finances; unpublished data, Federal Bureau of Investigation; Federal Outlays, 1969 (compiled by the Office of Economic Opportunity).

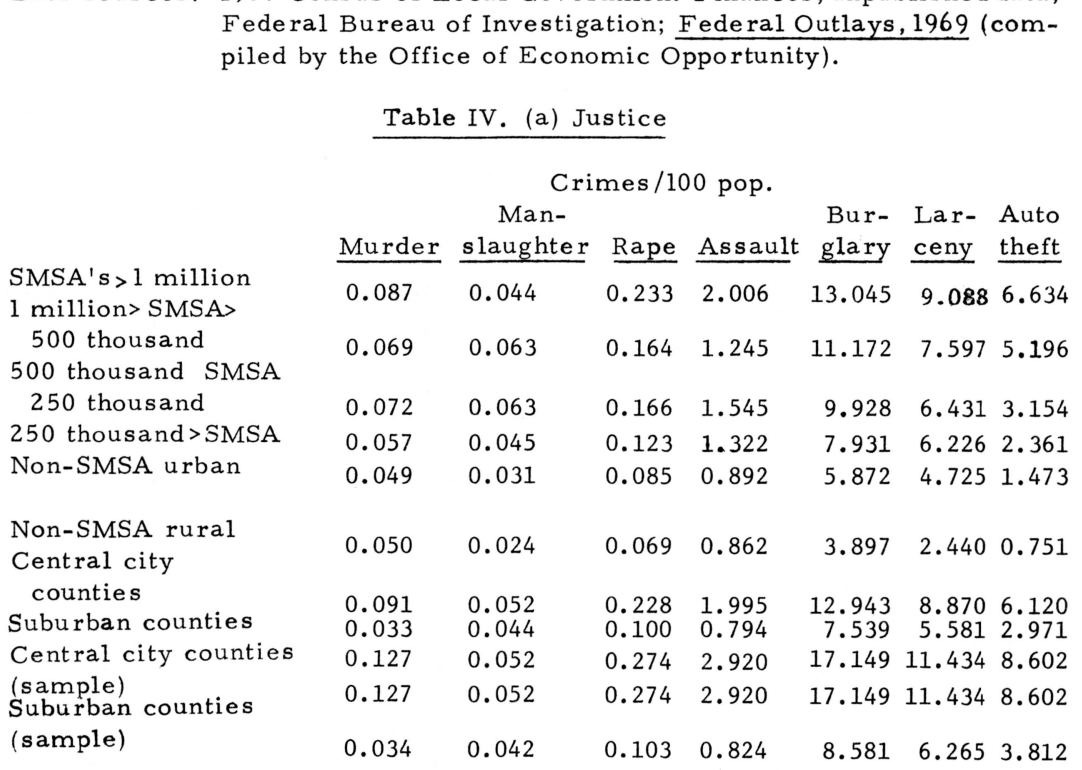

Law

Enforcement

$\frac{\text { Robberies/ }}{1,000 \text { pop. }}$

0.133

2.322

0.485

4.397

0.573
Assistance

\$/pop.

.03

.48

.05

.72

.03

Data source: Unpublished data, Federal Bureau of Investigation.

Table V. Health

\begin{tabular}{|c|c|c|c|}
\hline & $\begin{array}{c}\begin{array}{c}\text { Respiratory } \\
\text { deaths }\end{array} \\
\% \text { deaths } / \\
\% \text { pop. } \\
\end{array}$ & $\begin{array}{c}\text { Infant } \\
\text { mortality } \\
\text { rates } \\
\end{array}$ & $\begin{array}{c}\text { Age adjusted } \\
\text { death rates } \\
\end{array}$ \\
\hline SMSA's > 1 million & 0.98 & 21.9 & 9.7 \\
\hline 1 million $>$ SMSA $>500$ thous and & 0.98 & 21.0 & 9.4 \\
\hline 500 thousand $>$ SMSA $>250$ thousand & 0.94 & 21.7 & 9.4 \\
\hline 250 thousand $>$ SMSA & 0.92 & 22.1 & 9.4 \\
\hline Non-SMSA urban & 1.03 & 23.0 & 9.3 \\
\hline Non-SMSA rural & 1.08 & 24.4 & 9.5 \\
\hline Central city counties & 1.02 & 22.3 & 9.8 \\
\hline Suburban counties & 0.80 & -- & -- \\
\hline Central city counties (sample) & 1.20 & 24.2 & 10.3 \\
\hline Suburban counties (sample) & 0.80 & 19.6 & 8.7 \\
\hline
\end{tabular}


Data sources: Public Health Services, Vital Statistics of the United States, Volume II - Mortality.

\section{Table V. (a) Health}

SMSA's $>1$ million

1 million $>$ SMSA $>500$ thous and

500 thous and $>$ SMSA $>250$ thousand

250 thousand> SMSA

Non-SMSA urban

Non-SMSA rural

Central city counties

Suburban counties

Central city counties (sample)

Suburban counties (sample)

\begin{tabular}{|c|c|c|c|}
\hline \multicolumn{4}{|c|}{$\$ /$ pop } \\
\hline $\begin{array}{l}\text { Federal } \\
\text { health } \\
\text { services } \\
\text { and care } \\
\end{array}$ & $\begin{array}{l}\text { Federal } \\
\text { hospital } \\
\text { construc- } \\
\text { tion } \\
\end{array}$ & $\begin{array}{c}\text { Local } \\
\text { hospitals } \\
\end{array}$ & $\begin{array}{r}\text { Local } \\
\text { health } \\
\end{array}$ \\
\hline 21.1 & 2.4 & 18.2 & 4.4 \\
\hline 16.2 & 4.5 & 9.9 & 3.0 \\
\hline 17.2 & 1.7 & 10.6 & 2.3 \\
\hline 15.0 & 2.4 & 9.4 & 2.1 \\
\hline 14.3 & 2.9 & 13.8 & 1.9 \\
\hline 11.6 & 2.2 & 11.3 & 1.6 \\
\hline 21.4 & 3.0 & 16.3 & 3.9 \\
\hline 10.6 & 1.7 & 8.8 & 2.4 \\
\hline 33.7 & 3.5 & 29.1 & 6.7 \\
\hline 13.1 & 1.9 & 8.1 & 3.0 \\
\hline
\end{tabular}

Data sources: Federal Outlays, 1969 (compiled by Office of Economic Opportunity); 1967 Census of Local Government Finances.

\section{Table VI. Welfare}

\begin{tabular}{|c|c|c|}
\hline & $\begin{array}{c}\text { Local } \\
\text { expenditures }\end{array}$ & $\begin{array}{c}\text { Federal income } \\
\text { security } \\
\end{array}$ \\
\hline & $\$ /$ pop. & $\$ /$ pop. \\
\hline SMSA's $>1$ million & 31.9 & 36.9 \\
\hline 1 million $>$ SMSA $>500$ thousand & 15.4 & 24.8 \\
\hline 500 thousand $>$ SMSA $>250$ thousand & 15.6 & 27.1 \\
\hline 250 thousand $>$ SMSA & 10.6 & 24.5 \\
\hline Non-SMSA urban & 11.5 & 28.8 \\
\hline Non-SMSA rural & 11.9 & 37.0 \\
\hline Central city counties & 26.9 & 35.9 \\
\hline Suburban counties & 14.9 & 18.2 \\
\hline Central city counties (sample) & 45.9 & 52.3 \\
\hline Suburban counties (sample) & 20.5 & 19.9 \\
\hline
\end{tabular}

Data sources: 1967 Census of Local Government Finances; Federal Outlays, 1969 (compiled by the Office of Economic Opportunity).

Table VII. Actual Growth

\begin{tabular}{|c|c|c|c|c|}
\hline & $\begin{array}{l}\% \mathrm{C} \\
\text { Pop }\end{array}$ & $\begin{array}{l}\text { nge in } \\
\text { ation }\end{array}$ & $\begin{array}{r}\text { Annual } \\
\text { in po }\end{array}$ & $\begin{array}{l}\text { Change } \\
\text { lation }\end{array}$ \\
\hline & $1960-66$ & $1966-70$ & $1960-66$ & $1966-70$ \\
\hline SMSA's > 1 million & 10.5 & 5.4 & 1.75 & 1.35 \\
\hline $\begin{array}{l}1 \text { million }>\text { SMSA }>500 \text { thous and } \\
500 \text { thousand }>\text { SMSA }>250\end{array}$ & 11.3 & 7.4 & 1.88 & 1.85 \\
\hline thousand & 11.0 & 6.2 & 1.83 & 1.55 \\
\hline 250 thousand $>$ SMSA & 10.2 & 4.2 & 1.70 & 1.05 \\
\hline Non-SMSA urban & 8.2 & 2.8 & 1.37 & 0.70 \\
\hline
\end{tabular}


Table VII. Actual Growth (cont.)

Non-SMSA rural

Central city counties

Suburban counties

Central city counties (sample)

Suburban counties (sample)

United States

\begin{tabular}{|c|c|c|c|}
\hline \multicolumn{2}{|c|}{$\begin{array}{l}\% \text { Change in } \\
\text { Population }\end{array}$} & \multicolumn{2}{|c|}{$\begin{array}{c}\text { Annual } \% \text { Change } \\
\text { in population }\end{array}$} \\
\hline $1960-66$ & $1966-70$ & $1960-66$ & $1966-70$ \\
\hline 55.2 & 0.2 & 0.87 & 0.05 \\
\hline $\begin{array}{r}9.0 \\
117.0 \\
4.7\end{array}$ & $\begin{array}{r}4.4 \\
10.8 \\
0.6\end{array}$ & $\begin{array}{l}1.50 \\
2.83 \\
0.78\end{array}$ & $\begin{array}{l}1.10 \\
2.70 \\
0.15\end{array}$ \\
\hline $\begin{array}{r}18.7 \\
9.1\end{array}$ & $\begin{array}{r}10.7 \\
4.2\end{array}$ & $\begin{array}{l}3.12 \\
1.82\end{array}$ & $\begin{array}{l}2.68 \\
1.05\end{array}$ \\
\hline
\end{tabular}

Data sources: 1960, 1970 Census of Population; U.S. Bureau of the Census, Current Population Reports, Series p-25, No. 427, "Estimates of the Population of Counties and Metropolitan Areas, July 1, 1966."

Table VIII. Defense Payrolls

(2)

(1)

Population Program Concentration \% of U.S. \% of U.S. Ratios

Counties with lowest crime

Counties with highest crime

Counties with least air pollution

Counties with most air pollution

Counties with least water pollution

$\begin{array}{rrr}10.0 & 4.6 & 0.46 \\ 10.9 & 6.5 & 0.60 \\ 27.1 & 40.6 & 1.50 \\ 27.0 & 19.4 & 0.72 \\ 8.1 & 10.8 & 1.33 \\ 8.3 & 8.9 & 1.07 \\ 34.2 & 44.1 & 1.29 \\ 34.3 & 32.3 & 0.94 \\ 37.3 & 29.6 & 0.79 \\ 12.4 & 16.7 & 1.35 \\ 9.9 & 14.4 & 1.45 \\ 7.2 & 13.1 & 1.82 \\ 11.0 & 10.3 & 0.94 \\ 22.1 & 15.8 & 0.71 \\ 52.0 & 57.4 & 1.10 \\ 14.9 & 16.5 & 1.11 \\ 12.5 & 20.8 & 1.66 \\ 8.4 & 9.7 & 1.15\end{array}$

Counties with most water pollution

SMSA counties with least auto density

SMSA counties with most auto density

SMSA's $>1$ million

1 million $>$ SMSA $>500$ thousand

500 thousand $>$ SMSA $>250$ thousand 250 thousand $>$ SMSA

Non-SMSA urban

Non-SMSA rural

Central city counties

Suburban counties

Central city counties (sample)

Suburban counties (sample)

Data sources: Unpublished data from Federal Bureau of Investigation, National Air Pollution Control Administration, Federal Water Quality Administration, and Bureau of Public Roads. Federal Outlays, 1969 (compiled by the Office of Economic Opportunity). 
Counties with lowest crime

Counties with highest crime

Counties with least air pollution

Counties with most air pollution

Counties with least water pollution

Counties with most water pollution

SMSA counties with least auto density

SMSA counties with most auto density

SMSA's 1 million

1 million SMSA 500 thousand

500 thousand SMSA 250 thousand

250 thousand SMSA

Non-SMSA urban

Non-SMSA rural

Central city counties

Suburban counties

Central city counties (sample)

Suburban counties (sample)
(1)

Population $\%$ of U.S.

10.0

10.9

27.1

27.0

8.1

8.3

34.2

34.3

37.3

12.4

9.9

7.2

11.0

22.1

52.0

14.9

12.5

8.4
(2) Program Concentration $\%$ of U.S. Ratios

$\begin{array}{rr}2.4 & 0.24 \\ 10.1 & 0.93 \\ 40.7 & 1.50 \\ 34.4 & 1.27 \\ 8.1 & 1.00\end{array}$

10.1

1.22

32.6

0.95

1.60

$\begin{array}{ll}50.9 & 1.36 \\ 20.0 & 1.61\end{array}$

$\begin{array}{ll}50.9 & 1.36 \\ 20.0 & 1.61\end{array}$

$9.7 \quad 0.98$

$5.7 \quad 0.79$

$7.4 \quad 0.67$

$6.3 \quad 0.29$

$69.3 \quad 1.33$

$17.0 \quad 1.14$

$15.6 \quad 1.25$

$10.2 \quad 1.21$

Data sources: Same as Table VIII.

Table X. Atomic Energy

\begin{tabular}{|c|c|c|c|}
\hline & $\begin{array}{c}\text { (1) } \\
\text { Population } \\
\% \text { of U.S. }\end{array}$ & $\begin{array}{l}\text { (2) } \\
\text { Program } \\
\% \text { of U.S. }\end{array}$ & $\begin{array}{c}\frac{(2)}{(1)} \\
\text { Concentration } \\
\text { Ratios } \\
\end{array}$ \\
\hline Counties with lowest crime & 10.0 & 17.1 & 1.71 \\
\hline Counties with highest crime & 10.9 & 2.2 & 0.20 \\
\hline Counties with least air pollution & 27.1 & 29.5 & 1.09 \\
\hline Counties with most air pollution & 27.0 & 18.4 & 0.68 \\
\hline Counties with least water pollution & 8.1 & 21.3 & 2.63 \\
\hline Counties with most water pollution & 8.3 & 4.2 & 0.51 \\
\hline SMSA counties with least auto density & 34.2 & 22.8 & 0.67 \\
\hline SMSA counties with most auto density & 34.3 & 39.3 & 1.15 \\
\hline SMSA's > 1 million & 37.3 & 35.7 & 0.96 \\
\hline 1 million $>$ SMSA $>500$ thousand & 12.4 & 6.1 & 0.49 \\
\hline 500 thousand $>$ SMSA $>250$ thous and & 9.9 & 18.6 & 1.88 \\
\hline 250 thousand $>$ SMSA & 7.2 & 1.6 & 0.22 \\
\hline Non-SMSA urban & 11.0 & 17.5 & 1.59 \\
\hline Non-SMSA rural & 22.1 & 20.5 & 0.93 \\
\hline Central city counties & 52.0 & 37.2 & 0.72 \\
\hline Suburban counties & 14.9 & 24.8 & 1.66 \\
\hline Central city counties (sample) & 12.5 & 18.0 & 1.44 \\
\hline Surburban counties (sample) & 8.4 & 10.3 & 1.23 \\
\hline
\end{tabular}

Data sources: Same as Table VIII. 
Table XI. Space Research and Technology

Counties with lowest crime

Counties with highest crime

Counties with least air pollution

Counties with most air pollution

Counties with least water pollution

(1)

(2)

$\frac{(2)}{(1)}$

Population Program Concentration

$\%$ of U.S. $\%$ of U.S. Ratios

Counties with most water pollution

SMSA counties with least auto density

SMSA counties with most auto density

10.0

10.9

0.5

0.05

27.1

3.1

0.28

27.0

42.1

1.55

8.1

37.6

1. 39

7.2

0.89

8.3

9.4

1.13

34.2

28.4

0.83

34.3

57.6

1.68

SMSA's > 1 million

1 million $>$ SMSA $>500$ thous and

37.3

69.5

1.86

12.4

5.4

0.44

500 thous and $>$ SMSA $>250$ thous and

250 thousand $>$ SMSA

Non-SMSA urban

Non-SMSA rural

Central city counties

9.9

7.2

3.9

0.39

11.0

7.0

0.97

22.1

13.0

1.18

52.0

1.3

0.06

65.6

1.26

Suburban counties

Central city counties (sample)

14.9

20.2

1.36

Suburban counties (sample)

12.5

18.8

1.50

8.4

19.5

2.32

Data sources: Same as Table VIII. 
Table XII.

(All Numbers In \% Of U.S. Total)
Counties with lowest crime

Counties with highest crime

Counties with least air

pollution

Counties with most air

pollution

Counties with least water

pollution

Counties with most water pollution

SMSA counties with least auto density

SMSA counties with most

auto density

Counties with lowest per-

cent completed high school

Counties with highert per-

cent completed high school

\begin{tabular}{cc} 
Pop. & $\begin{array}{c}\text { Law } \\
\text { enforcement } \\
\text { assistance }\end{array}$ \\
\cline { 2 - 2 } 10.0 & 3.2 \\
10.9 & 16.2
\end{tabular}

27.1

27.0

8,1

8.3

34.2

34.3

10.0

\begin{tabular}{lll}
$\begin{array}{c}\text { Air pol- } \\
\text { lution }\end{array}$ & $\begin{array}{c}\text { Water } \\
\text { pollution } \\
\text { control }\end{array}$ & $\begin{array}{c}\text { Urban } \\
\text { mass }\end{array}$ \\
\hline
\end{tabular}

\section{Elementa ry}

and

education

28.3

56.1

13.1
80.5

19.0 
Table XII.

(All Numbers In \% Of U.S. Total)

Continued

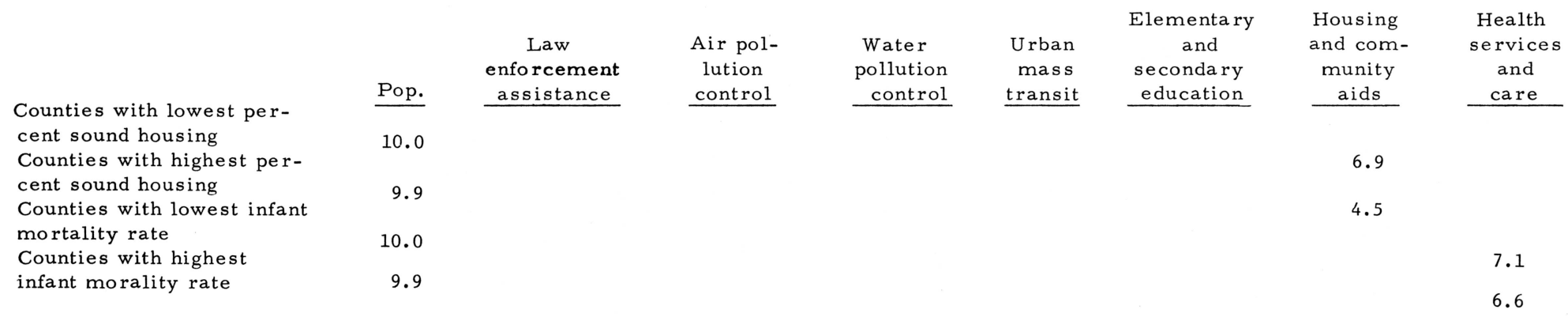

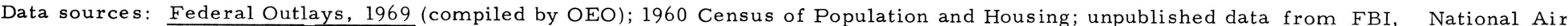
Pollution Control Administration, Federal Water Quality Administration, Bureau of Public Roads; and Public Health Service, Vital Statistics of the United States, Volume II - Mortality. 
FOOTNOTES

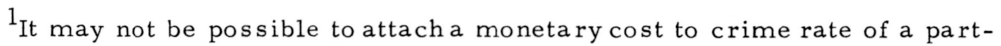
icular level and then add it directly to local government expenditures for police to get an overall cost of crime associated with a particular area. Certain more limited statements, however, can be made. If two areas spend roughly the same amount per capita on police protection, but the second has a crime rate significantly higher than the first, then the cost of crime is clearly higher in the second area.

2 This analysis was inspired by and attempts to extend analysis by Roger Noll in "Urban Concentration: Prospects and Implication," in Increasing Understanding of Public Problems and Polices, Farm Foundation, Chicago: 1969, pp. 121-131.

${ }^{3}$ The ideal denominator would have been population between 5 and 18, but this was not available for the population base year 1966 .

${ }^{4}$ All the other crimes which comprise the index of crime computed by the Federal Bureau of Investigation replicate the pattern revealed by data on robberies with varying degrees of similarity.

${ }^{5}$ Federal appropriations for this activity have been growing rapidlysince 1969 so that the display of dollars per person considerably understate current outlays levels.

${ }^{6}$ Overresponse to the stimulus of growth in the formof immigration could nullify or even reverse this conclusion, but the most likely response would not be of such a magnitude. See Robert Raynsford, "Notes on the Relationship Between Job Creation, Intercounty Migration, Unemployment, and Family Income", The Review of Regional Studies Vol. I, No. 1.

${ }^{7}$ Robert Raynsford, "Locational Analysis of Federal Expenditures in Fiscal Year 1969" (Report of the Joint OMB-EDA Locational Analysis Project), Office of Management and Budget, September 1, 1970.

8 Automobile density is expressed as automobiles per person.

${ }^{9}$ The two measures of water quality used in this study were dissolved oxygen in milligrams per liter and coliforms in $\mathrm{MF} / 100 \mathrm{ml}$. Tables VIII-XI report findings based only on dissolved oxygen data, which we re available for 299 counties. 